\title{
IMPROVING THE IMPLEMENTATION OF GOOGLE MEET TO IMPROVE THE ASPECT AND THE COMPONENT OF SPEAKING SKILL ON THE STUDENTS FROM NON ENGLISH SPEAKING BACKGROUND
}

\author{
Mutakhirani Mustafa \\ Natalia Manuhutu \\ Fransiska Densiana Luruk \\ State Institute for Islamic Studies (IAIN) Syekh Nurjati Cirebon \\ E-mail: mutakhiranimustada@gmail.com
}

\begin{abstract}
Abstrak
The purpose of this study is to investigate how the use of google meet can improve the speaking ability of students of iain Intensive English 1 program Syekh Nurjati Cirebon. This particular research is categorized as action research. These actions are performed in three cycles based on the class schedule. The study involved 35 students. This research data is qualitative and quantitative data. Qualitative data is obtained by observing the teaching and learning process in speaking classes. Meanwhile, quantitative data is obtained through tests, and questionnaires. The findings suggest that the use of Google Meet terbukti meningkatkan keterampilan berbicara mahasiswa. Therefore google meet is very suitable to be used as online or virtual learning especially in improving students' speaking skills that focus on aspects and components of student speaking skills, but there are some drawbacks that can make learning less effective and less efficient when used as a particular application in the learning and teaching process. Therefore, all educators who use application media such as google meet are able to master and professional in using the application. Hopefully this pandemic ends quickly and we can adjust how the future of education around the world goes forward. For the next researcher, can be focused on the influence of the implementation of google meet application in speaking subjects to the interest of students to improve speaking. Based on this study, researchers found students' enthusiasm is very high in learning to speak, this proves that the google meet application can improve aspects and components of student speaking because it is influenced by increased student motivation during the use of google meet application compared to other applications.
\end{abstract}

Keywords: Google Meet, Speaking Skill, Students 
Datokarama English Education Journal Vol.2 No. 2, 2021

\section{Background}

Language is a skill where skills must be continuously trained and used to improve good and correct language skills. One of the languages that must be known by students in this era is English, especially students. It is not easy to master english apatahlagi this language is a foreign language that not all people use this language. English is a course that requires a special learning design during the Covid-19 pandemic (Ulfa, 2020) ${ }^{1}$. This is because nowadays during the Covid-19 pandemic, learning is being delivered through online learning environments. Therefore, English is a foreign language that requires time and regular practice to improve students' skills in English courses. (Helmi. 2020) English has four skills, in learning a language there are four aspects of language skills that must be mastered in students, namely fields, the ability to speak English or a second language is needed ${ }^{2}$. There are four skills in English, namely reading, speaking, listening and writing. To improve the skills of students on these four skills, all that is needed is not only the theory but the application of practice in its implementation. Harmer (2007) states that there are three main reasons for making students speak in class $^{3}$. First, speaking activities provide training opportunities to practice speaking in real life in a safe class. Second, speaking assignments where students try to use one or all of the languages, they know provide feedback for lecturers and students. Therefore, lecturers who are able to study

${ }^{1}$ Ulfa, S., Surahman, E., \& Octaviani, H. I. (2020, December). Mobile Seamless Language Learning Framework to Improving Students' Speaking Skills for Junior High Students during Pandemic Convid19: A Case Study in Indonesian Context. In 1st International Conference on Information Technology and Education (ICITE 2020) (pp. 497500). Atlantis Press.

${ }^{2}$ Helmi, M. Google Meet as a Media to Improve English Language Speaking Skills in E-Learning in Grade 11 at SMK NU Banjarmasin.

${ }^{3}$ Harmer, J. (2007). How to teach English (new ed.). England: Pearson Education Limited.
English are expected to be able to address student issues and meet the needs of students who must be achieved even though the lectures are conducted online. Especially how to improve student speaking by using online learning applications.

Many learning applications become a medium for the teaching and learning process but not all of these applications can provide a platform to improve student speaking. Because to improve the skills or english skills of students is not young that is required regular practice and the right strategy. In face-to-face lectures alone the majority of students get a number of obstacles to improve speaking apatahlagi in non-face-to-face lectures. The right selection of learning applications is needed by students in the online lecture period to improve speaking skills.

\section{Literature Review}

In general, speaking skills are divided into four namely Fluency or Fluency, Vocabulary, Grammar, Pronounciation. At least students can increase these points after following the learning process. To increase these points many media that can be used as in research (Bawanti and Arifani, 2021) The Students' Perceptions of Using Zoom Application on Mobile Phone in Improving Speaking Skills During Online Learning ${ }^{4}$. In the research shown that online learning on the use of the Zoom application has a positive impact on students performance in the speaking skill. The studests gave positive respone on the application because they spoke impproved by using that application during learning speaking skills speacially their fluency, vocabulary, grammar and pronounciation. Not only by using zoom meeting but many learning application help

${ }^{4}$ Bawanti, P. K. D., \& Arifani, Y. (2021). The Students' Perceptions of Using Zoom Application on Mobile Phone in Improving Speaking Skills During Online Learning at Ban Loeiwangsai School, Loei Province, Thailand. Journal of English Teaching, Literature, and Applied Linguistics, 5(1), 54-61. 


\section{Datokarama English Education Journal Vol.2 No. 2, 2021}

students to improve their speaking. Other research proved in (Syafiq and et al,2021) increasing speaking skill through youtube video as english learning material during online learning in pandemic covid $19^{5}$. In this research found that youtube video as learning youtube material improved speaking skill of students including fluency, vocabulary, pronunciation, grammar and content. Based on the result of the study, it can be concluded that youtube application help students in improving their speaking skill.

In addition, (Setiawan and Suhartini, $2021)^{6}$ other research also shown the successfull of the leaning application in improving speaking skills of the students. In the reserach by tittle whatsapp voice note in speaking class, the result proved that whatsapp voice note had positive respone of the students because it was attractive learning activity, positive activity and easy activity. Therefore the students enjoyed using that application in speaking. Although using voice note tinggkat success is not maximal because using voice note requires the desire and motivation of students to listen whether it's the explanation of the lecturer or listening to the conversation. Voice note is also a feature of whatsapp that we know that this application is a social media application that is not customized specifically for online learning so many features are not relevant for online learning.

(Syamimie and Syakira, 2019) $^{7}$ The newest research of learning application for

\footnotetext{
${ }^{5}$ Syafiq, A. N., Rahmawati, A., Anwari, A., \& Oktaviana, T. (2021). Increasing Speaking Skill through YouTube Video as English Learning Material during Online Learning in Pandemic Covid-19. Elsya: Journal of English Language Studies, 3(1), 50-55.
}

${ }^{6}$ Setiawan, B., \& Suhartini, L.2021. The Effect of Using Video on Students' Speaking Skill Through Whatsapp Application at SMA Negeri 1 Kabangka. Journal of Teaching of English, 6(1), 96100.

\footnotetext{
${ }^{7}$ Syamimie, M. N. N., Lena, R., \& Syakira, S. 3019. STUDENTS RESPONSE TO USING TELEGRAM IN SPEAKING PRACTICE DURING SELF LEARNING TIME.
}

speaking skill was students response to using telegram in speaking practice during self learning time. In the research shown the most significant finding revealed that students display high positive attitudes towards the use of Telegram in practising their English speaking skill outside of the formal class. The problem is many students that try to improve their speaking geeting bored in the learning process by using telegram because the application is not for specially learning application but it is general. The feature is not helping a lot for the students to increase their speaking. The last research related of Gangaiamaran, R., \& Pasupathi, M. (2017) ${ }^{8}$. The use of online learning application to improve speaking skill of the students is using onle video to improve speaking abilities of EFL learners. Results shown that those who watched videos improved their speaking ability and they had high scored than those who didn't, and in view of gender, the girls were more successful than the boys. Thus, the reserach can be conclude that using online videos in classes can be of vital importance and effective in improving EFL learners' speaking ability. The research suggested to the students watching some english learning videos that took from some application such as You Tube, BBC English Learning, BBC News, British Council, and VOA Learning English. The weakness of this research is not all the students getting akses to those application speacially the students who are in the remote areas. Thus, the sucucessful of this strategy is based on the location and the background of the students.

Based on a number of previous studies, where most use some online learning applications in improving speaking students the majority get a positive response and can give a positive influence to improve student speaking although in general and not really influence the aspect of speaking skills in

\footnotetext{
${ }^{8}$ Gangaiamaran, R., \& Pasupathi, M. (2017). Review on use of mobile apps for language learning. International Journal of Applied Engineering Research, 12(21), 11242-11251.
} 
detail. Researchers have not found any research that uses google meet to improve student speaking in some aspects. As we know google meet is one of the learning applications that offers some convenience and is very suitable to improve student speaking. Therefore, researchers initiated to use google meet in improving student speaking and student speaking competencies, including knowledge competency, action and attitude. Researchers will conduct research on whether using google meet in speaking learning can help lecturers and students in improving students' speaking skills during online learning, especially on three competencies in speaking skills.

\section{Methodology}

This type of research is Classroom Action Research, abbreviated car. Researchers chose this type of research to improve the quality and improve the teaching and learning process in the classroom for the better. Class action research is done over and over again, the process is observed earnestly until the perceived process gives better results than before. In the process of troubleshooting on this research model use steps and strategies to achieve maximum results. In practice in this type of research consciously formulate an action in the classroom with delandation with science and strategy so that the results of this study is believed to contribute to the improvement especially in teaching and learning activities. It shows that action research is conducted in the local environment and is conducted for the purpose of improvement by introducing more effective teaching strategies. Meanwhile, Burns (2010) stated that the central idea of the action research section in education is to deliberately intervene in problematic situations to produce changes and improvements in practice. So in the context of this study researchers conducted action research on a local scale where the situation and location are in the classroom that is precisely conducting class action research to advance the teaching and learning process more effectively. Research data is qualitative and quantitative.

Qualitative data is obtained through observations related to the learning process of teaching and speaking in the classroom. Quantitative data obtained from tets speaking to measure the increase of speaking students in the teaching and learning process. Where students make speeches to make observations and assess the improvement of speaking aspects and speaking competencies. Qualitative data collection through questionnaires is intended to find out about understanding, ease, constraints and various other factors they experience when using the Google Meet application in learning to develop speaking skills. This form of test is to maximize the use of applications used as media for distance learning or E-Learning, which includes developing skills. The google meet application is one of the solutions in increasing the use of technology in the learning process, it aims to facilitate learning process like in the real classroom.

\section{Result and Discussion}

This study uses Class Action Research Method which consists of several stages, namely planning, implementation, observation and reflection for cycle 1 , cycle 2 and cycle 3.Researchers use three cycles where each cycle consists of planning, implementation and evaluation to get accurate data about the influence of google meeet application on speaking students. Researchers used tests through pretest and posttest, pretest and posttest administered to find out their improved speaking ability. Skills after students follow all activities. 
Datokarama English Education Journal Vol.2 No. 2, 2021

Tabel1.Pretest,

\begin{tabular}{|c|l|l|l|l|l|}
\hline $\begin{array}{c}\text { criteria } \\
\text { for } \\
\text { speaking } \\
\text { aspects }\end{array}$ & Grammar & pronunciation & Fluency & comprehension & Vocabulary \\
\hline & 65.35 & 66.95 & 67.35 & 69.37 & 66.20 \\
\hline
\end{tabular}

Based on the table above can be explained that the speaking ability of students is still very low. This can be observed from the achievement of scores in every aspect. This data is retrieved before using the google meet app. It is influenced by several factors, including the motivation of students to learn English is still fairly low and their environment is less supportive to learn English so that students' confidence to learn English is very lacking. In addition, each student lacks mastering and understanding related to five aspects of speaking skills, namely grammar, pronunciation, fluency, comprehension, and vocabulary. Plus during the pandemic the government implemented the application of online learning so that educators must think about the right strategies and approaches to improve the quality of students' online learning. It is not easy to improve

\begin{tabular}{|c|l|l|l|}
\hline $\begin{array}{c}\text { criteria for } \\
\text { speaking } \\
\text { competency }\end{array}$ & Knowledge & Action & Attitude \\
\hline & 65.22 & 66.33 & 65.55 \\
\hline
\end{tabular}

Based on the table above, it can be concluded that students' speaking competence is knowledge, action and attitude is also low in speaking. This is evident from data taken by researchers before using the google meet app. Therefore, researchers do treatmen by utilizing google meet to improve all three competencies of students through online. To increase students' knowledge in speaking is not difficult where the main thing they need is motivation why students should improve knowledge competence because when they speak English but the knowledge is lacking then greatly influence their actions and attitudes in speaking. students' speaking in the online learning process.

During the teaching and learning process, the author observes each stage, and records important events or things during class. After the learning process is complete, the author concludes that there are things that need to be developed in order for the learning target to be achieved properly. In addition to the five aspects of speaking skills that need to be improved students must also improve speaking competencies, namely knowledge, action and attitude competencies. Based on the pre test conducted by researchers through observations, interviews and questionnaires to find out the speaking competence of students in the target class, the results are as follows.

Tabel 2. Criteria for Speaking Competency 
Datokarama English Education Journal Vol.2 No. 2, 2021

\section{Tabel 3. Cycle 1 and Post Test 1}

\begin{tabular}{|c|l|l|l|l|l|}
\hline $\begin{array}{c}\text { criteria } \\
\text { for } \\
\text { speaking } \\
\text { aspects }\end{array}$ & Grammar & pronunciation & Fluency & comprehension & Vocabulary \\
\hline & 81.24 & 82.11 & 82.13 & 80.75 & 81.70 \\
\hline
\end{tabular}

Based on the table above, it appears that the posttest 1 results showed a very significant increase in scores on each of the speech skill criteria. It is also seen from the observations during the teaching and learning process that students look very enthusiastic when using google meet applied in speaking classes. Some students even enthusiastically try to recite every sentence they hear. Students have high

\begin{tabular}{|l|l|l|l|}
\hline $\begin{array}{c}\text { Criteria for } \\
\text { speaking } \\
\text { competency }\end{array}$ & Knowledge & Action & Attitude \\
\hline & 78.88 & 79.78 & 79.88 \\
\hline
\end{tabular}

Based on the table above shows an improvement although the improvement is not very significant in terms of student speaking competence, namely knowledge, action and attitudenya. This is based on tests and observations conducted where the level of student year increases after a few days of teaching and learning activities through google meet not only knowledge but the initiative of students to issue opinions also

confidence in speaking, expressing opinions and asking questions using this application whether it is addressed to their teacher or to their classmates. In the first cycle after the use of google meet application at least showed positive results in improving student speaking.

\section{Tabel 4. Cycle 1 and Post Test 1}

\begin{tabular}{|c|l|c|l|l|l|}
\hline $\begin{array}{c}\text { criteria of } \\
\text { speaking } \\
\text { aspect }\end{array}$ & Grammar & pronounciation & Fluency & comprehension & Vocabulary \\
\hline & 82.27 & 81.20 & 81.26 & 81.84 & 82.70 \\
\hline
\end{tabular}

Based on the table above it appears that students' speech ability has improved when compared to the results of $\mathrm{T}$ cycle 1 . This certainly proves that the use of google meet greatly affects the level of student speech achievement. skills in listening and academic speaking courses. The google meet app helps students think critically, understand text, identify core ideas, improve vocabulary, and finally draw conclusions from text. Students are motivated to think critically, understand the text, identify the main idea, improve vocabulary, and finally draw conclusions from the text easily because of the stimulus done by researchers in providing treatmen to improve the speaking aspect using this application. It is strongly supported also by a number of features prepared by google meet among which researchers can do share screen, share reading, share video. In addition, students can also feed back content during the learning so that students feel comfortable using this application without time restrictions and researchers can also explain each slide. 
Datokarama English Education Journal Vol.2 No. 2, 2021

Tabel 6. Cycle 2 and Post Test 2

\begin{tabular}{|c|l|c|l|}
\hline $\begin{array}{c}\text { criteria for } \\
\text { speaking } \\
\text { competency }\end{array}$ & Knowledge & Action & Attitude \\
\hline & 80.00 & 81.00 & 81.22 \\
\hline
\end{tabular}

Based on the table above shows an increase from cycle 1 to cycle 2 in terms of students' speaking competence, namely knowledge, action and attitude. This is based on tests and observations conducted where the level of student year increases after a few days of learning activities through google meet not only knowledge but the initiative of students to issue opinions also increases speaking. Students also seem enthusiastic without any awkwardness and embarrassment to bring out the ability to speak in addition to other students by observing describing good behavior in speaking and listening.

Tabel 7. Cycle 3 and Post Test 3 accompanied by a supportive attitude in

\begin{tabular}{|c|l|l|l|l|l|}
\hline $\begin{array}{c}\text { criteria of } \\
\text { speaking } \\
\text { aspect }\end{array}$ & Grammar & pronounciation & Fluency & comprehension & Vocabulary \\
\hline & 84.27 & 84.20 & 83.26 & 83.84 & 86.70 \\
\hline
\end{tabular}

Based on the table above, it appears that students' speech ability has improved when compared to the results of cycle test 1 and cycle test 2 . This certainly proves that the use of google meet greatly affects the level of student speech achievement. skills in listening and speaking academical courses if this treatment is applied continuously, especially in online learning. The google meet app helps students think critically, understand text, identify core ideas, improve vocabulary, and finally draw

\begin{tabular}{|c|l|l|l|}
\hline $\begin{array}{c}\text { criteria for speaking } \\
\text { competency }\end{array}$ & Knowledge & Action & Attitude \\
\hline & 82.22 & 83.34 & 85.44 \\
\hline
\end{tabular}

Based on the table above shows a significant improvement after the use of google meet application applied during some meetings. Students' ability in terms of students' speaking competence, namely knowledge, action and attitude, increases drastically based on observations and tests conducted in cycle 3 . This proves that the use of google meet application is very effectively used as an alternative learning application in speaking subjects.

Helmi, M. 2020 ${ }^{9}$. Google Meet used conclusions from text. Based on the results of the above study, the authors can conclude that the use of google meet application can improve students' grades. So google meet application is an application that helps in teaching and learning activities in the classroom, especially speaking learning in English.

Tabel 8. Cycle 3 and Post Test 3

to be the name of this application is "Hangout" however, due to the rampant demand for mass video conferencing applications amid the pandemic. finally, now Google Meet is a simple, economical, and effective application as we know it today, very useful for meetings, discussions and online learning. In the latest version of Google Meet which is updated on 11 November 2020, Google Meet google meet

Language Speaking Skills in E-Learning in Grade 11 at SMK NU Banjarmasin. 
has a variety of features that support all learning activities specially speaking activity during the class, among others are : a. There is no limit to the participants in each meeting b. Each meeting can be connected with other applications c. Very easy to use device d. Real-time Video and audio preview screen. Screen in share can be set and adjusted to the comfort of students f. During the passage of learning can be controlled by the teacher assistent as host g. Presentation screen or material can be easily shown by students as well as students can show the screen h. Both educators and students can ask questions through the chat field set up by the app. This application is one of the structured learning applications and very easy to use whether it is in the teaching and learning process, conferences or other meetings.

Description related to student answers to the questionnaire results in the study. First is about the quality of the google meet application in the speaking class, second the activeness of students in virtual meeting, third is how often do you hone your speaking skills, fourth is how important they think it is to improve their speaking ability and the last is comparative question, whether online learning via Google Meet is more effective than face-to-face learning in class to improve speaking ability.

The results of research on 35 students in non english backgroud in the form of the answers are grouped into several statements representing several answers that are the same or agree. Therefore, that it makes it easier for researchers to describe the results of the study. the results of the questionnaire are as follows: 1) The first question about the quality of the Google Meet application in speaking class. Of all the participants, they stated that with this application media in the implementation of speaking classhad good quality, for a while in this new era of normality. It was evidenced by the description of the results of their answers where the same answers were grouped as follows: "Based on my argument, the google meet application is good qualityto help the students in improving our speaking ability, because it makes it easier for us to do distance learning and we can access it during class hours or outside class hours, we can be free giving the argument without hesitation but for effectiveness in improving speaking ability, I prefer for face to face meeting. " From this answer, he strongly agrees that the application used makes the learning benefit for the students. 2) The second question is whether students become more active in speaking skills during online learning. Of the 35 students who responded to the questionnaire, it could be said that $80 \%$ said their speaking skills had improved and $20 \%$ said they became quiet during learning process. "Yes, my speaking skills have improved, because during online learning, I feel there is no pressure, it's different when talking to friends in front of the class." From the answer of perceptions of this student she feels more confident because during online learning process, felt like no pressure not like speak in front of class like usual. Then another comment from the student who felt he became a quiet person during learning. "during learning I had difficulty focusing and also because of internet connection problems in my place." 3) Third question, most of their answers were only when asked or given time by the teacher to speak, then they began to hone their Englishspeaking skills. 4) The fourth question is how important they think it is to learn speaking ability (27 students). This is intended to find out their opinion about the importance of learning language and its components. This is evidenced by the description of the results of the answer as follows: "In my opinion it is very important because besides practicing speaking we can also gain extensive knowledge, because English is an international language. and if we master it we can understand all the knowledge that is on earth, because everyone uses it and we can hold the world". From the answers or perceptions of a student above on the importance of 
speaking class. In this statement, according to him, it is very important because by learning the ability to speak in English we can also expand knowledge and he can develop ideas with people around the world who speaks English too and we can convey our opinion about some issue in our country to carry out to international issue." Other students said "It is important, especially for us as language learners". 5) The fifth question is only a comparison of whether students prefer this kind of learning or prefer face-to-face learning as usual in the real classroom. Their answers vary, some like learning like this, because it is considered more time and cost effective, and many also don't like online learning like this because dealing with their smartphones it will be difficult to focus on their school which is implemented online. There are also those who want the corona to disappear quickly because they want to meet their classmates and already miss the teachers.

The results of the pre test and post test conducted to test whether the google meet application can help students in improving speaking ability show positive results. Where there are several advantages that this application has in facilitating students in speaking learning, among others, the features that this application has are very helpful to students such as; 1 . Between students and between students and teachers can come face to face to communicate with each other directly, 2 . The google meet app also has a share screen so that when a teacher or student is willing to make a presentation can display the points or materials easily, 3. The chat feature set up by this application can also help students if they want to ask questions but do not get the opportunity because of the large number of questions asked directly,4. This application also includes a lightweight application and does not use too high internet capacity it is very helpful for students, 5. Not limited to time and not paid so that students can freely practice their speaking skills, 5. There are automatic attendances available for teachers to see to ensure the number of students participating in learning at each meeting, 6. The app is also easy to use and easily accessible to anyone.

From the results of the data obtained can conclude that the google meet application can be used to improve the speaking of students especially and these results are also supported by some research that uses this application or other learning applications among them; 1 . Fakhruddin, A. $(2018)^{10}$. Google meet could improve speaking skills of students. skills can be identified from the improvement of speaking skill achievement. Hail this research based on those conducted by researchers with different situations and conditions but the same application and learning that is speaking class. Researchers concluded that the use of google meet application is very effective in supporting students to improve their speaking ability, 2. in addition there are also research results that state the google meet application is effective and efficient in improving the speaking ability of ironsi students, C. S. (2021) ${ }^{11}$ Although the use of google meet is adjured effective and efficient, this contextual overview of google meet is a new insight into academia. So this application can be an alternative for teachers and students in improving speaking skills, 3. The results of other studies also showed positive results where using google meet can improve especially pronunciation and intonation of students in speaking Iyehezkiel, I., \&Wiradisastra, G. J. T. (2021, January) ${ }^{12}$. Google meets was

\footnotetext{
${ }^{10}$ Fakhruddin, A. (2018). Using Google Meet in Teaching Speaking. Journal of English Language Learning (JELL), 2(2), 43-46.

${ }^{11}$ Ironsi, C. S. (2021). Google Meet as a synchronous language learning tool for emergency online distant learning during the COVID-19 pandemic: perceptions of language instructors and preservice

${ }^{12}$ Iyehezkiel, I., \& Wiradisastra, G. J. T. (2021, January). THE USE OF SMART PHONES TO IMPROVE
} 
good improvement which it was made good in pronunciation and intonation of the students, 4 From the results of other studies also showed that the influence of the use of google meet application is very siknifikan to enthusiastic students in improving their speaking skills so that every aspect of speaking and speaking component of students easily increased due to the positive response and learning motivation from students increased, Putra, R. W. P. $(2021)^{13}$. Using google meet of the result showed that the students actively participated and engaged in the teaching-learning process. The students were very enthusiastic to respond and answer the some questions, and share their ideas related to the topic of the meeting. In addition, the increase of students' motivation influence the students to compose sentences correctly related to the given assignments. Based on the research finding and supporting of the some researches therefore the researchers concluded that the implementation of google meet in speaking class improved students' speaking skill of the each aspect and each component in speaking.

\section{Conclusion and Suggestion}

Based on the results of the above research can be concluded that google meet application can improve students' speaking skills. The improvement of students' speaking skills can be seen from the improvement of speech skills achievement, namely where the aspects of grammar, pronounciation, fluency, comprehension and vocabulary of each student increase slowly

SPEAKING SKILLS AND TO DEVELOP INDEPENDENT LEARNERS. In PROSIDING SENANTIAS: Seminar Nasional Hasil Penelitian dan Pengabdian kepada Masyarakat (Vol. 1, No. 1, pp. 991-1002).

${ }^{13}$ Putra, R. W. P. (2021). Improving the Students' Motivation in Learning English through Google Meet during the Online Learning. English Learning Innovation, 2(1), 35-42 in each cycle. This data can be proven from the results of pretest and posttest taken in online classes, before the implementation of the use of google meet application, the results are less in terms of speaking aspects of students and the data obtained after the application of google meet in speaking classes increases in each cycle. Not only the speaking aspect of students is increasing but the speaking component of students also increases from each cycle of data obtained from test results, interviews, observations and questionnaires.

In this research, it is aimed to find out and discuss the use of one of the funtion learning application in developing speaking skills in English. English speaking skills are very important to study and improve, because English is an international language therefore that by learning speaking aspect and component that we can broaden our knowledge, action and our attitude. A student's understanding depends on the teacher's learning strategy and method implementing in the virtual class.It is not easy to manage the online class for the students specially for the teacher who has poor experience in using technology. In Google Meet application it is felt that teachers really need to adjust the learning as lightly as possible to make it more effective, and they need the assertiveness of a teacher to manage the class in difficult circumstances to monitor these students because it is carried out online. Here the teacher needs to know what the students need. Google Meet is a very good learning application, by comprehensive features for virtual learning and teaching process.

Therefore that this google meet is very suitable for use as an online or virtual learning specially in improving students speaking skill, but there are several shortcomings that can make learning less effective and less efficient when it use as certain application in learning and teaching process. Therefore, all of the educators that use the application media such as google meet are able to master and be professional in their use the application. Hopefully this 
Datokarama English Education Journal Vol.2 No. 2, 2021

pandemic will end quickly and we can adjust how the future of education around the world is going next. For the next researcher, it can be focus on the influnce of the implementation google meet in speaking class to the students. Based on this reserach , the researcher found surprising of respond of the student that their motivation was improved each meeting by using this application. 


\section{Datokarama English Education Journal Vol.2 No. 2, 2021}

Bawanti, P. K. D., \& Arifani, Y. (2021). The Students' Perceptions of Using Zoom Application on Mobile Phone in Improving Speaking Skills During Online Learning at Ban Loeiwangsai School, Loei Province, Thailand. Journal of English Teaching, Literature, and Applied Linguistics, 5(1), 54-61.

Burns, A., 2010. Doing Action Research in English Language Teaching: A Guide for Practitioners. Routledge. NewYork.

Fakhruddin, A. (2018). Using Google Meet in Teaching Speaking. Journal of English Language Learning (JELL), 2(2), 43-46.

Gangaiamaran, R., \& Pasupathi, M. (2017). Review on use of mobile apps for language learning. International Journal of Applied Engineering Research, 12(21), 11242-11251.

Henning, J.E., Stone, J.M., and Kelly, J.L.,2009. Using Action Research to Improve Instruction: an Interactive Guide for Teachers. London: Routledge

Helmi, M. Google Meet as a Media to Improve English Language Speaking Skills in E-Learning in Grade 11 at SMK NU Banjarmasin.

Harmer, J. (2007). How to teach English (new ed.). England: Pearson Education Limited.

Ironsi, C. S. (2021). Google Meet as a synchronous language learning tool for emergency online distant learning during the COVID-19 pandemic: perceptions of language instructors and preservice

Iyehezkiel, I., \& Wiradisastra, G. J. T. (2021, January). THE USE OF SMART PHONES TO IMPROVE SPEAKING SKILLS AND TO DEVELOP INDEPENDENT LEARNERS. In PROSIDING SENANTIAS: Seminar
Nasional Hasil Penelitian dan Pengabdian kepada Masyarakat (Vol. 1, No. 1, pp. 991-1002).

Putra, R. W. P. (2021). Improving the Students' Motivation in Learning English through Google Meet during the Online Learning. English Learning Innovation, 2(1), 35-42.

Richards, J. (2008). Teaching Listening and Speaking from Theory to Practice. NewYork: Cambridge University Press.

Syafiq, A. N., Rahmawati, A., Anwari, A., \& Oktaviana, T. (2021). Increasing Speaking Skill through YouTube Video as English Learning Material during Online Learning in Pandemic Covid-19. Elsya: Journal of English Language Studies, 3(1), 50-55.

Setiawan, B., \& Suhartini, L.2021. The Effect of Using Video on Students' Speaking Skill Through Whatsapp Application at SMA Negeri 1 Kabangka. Journal of Teaching of English, 6(1), 96-100.

Syamimie, M. N. N., Lena, R., \& Syakira, S. 3019. STUDENTS RESPONSE TO USING TELEGRAM IN SPEAKING PRACTICE DURING SELF LEARNING TIME.

Ulfa, S., Surahman, E., \& Octaviani, H. I. (2020, December). Mobile Seamless Language Learning Framework to Improving Students' Speaking Skills for Junior High Students during Pandemic Convid-19: A Case Study in Indonesian Context. In $1 s t$ International Conference on Information Technology and Education (ICITE 2020) (pp. 497-500). Atlantis Press. 